Article

\title{
Guidelines for Operationalizing Policy Coherence for Development (PCD) as a Methodology for the Design and Implementation of Sustainable Development Strategies
}

\author{
Harlan Koff ${ }^{1,2}, *$, Antony Challenger ${ }^{2}$ (i) and Israel Portillo ${ }^{2}$ \\ 1 Department of Geography and Spatial Planning, University of Luxembourg, Maison des Sciences Humaines, \\ 11, Porte des Sciences, L-4366 Esch-Belval, Luxembourg \\ 2 GAMMA-UL Chair for Regional Integration and Sustainability, Instituto de Ecología, A.C. (INECOL), \\ Carretera antigua a Coatepec 351, El Haya Xalapa 91070, Mexico; challenger.acb@gmail.com (A.C.); \\ jportilloperalta@gmail.com (I.P.) \\ * Correspondence: Harlan.koff@uni.lu; Tel.: +352-466-644-6270
}

Received: 26 February 2020; Accepted: 11 May 2020; Published: 15 May 2020

\begin{abstract}
Policy Coherence for Development (PCD) is considered a pillar of the 2030 Sustainable Development Agenda. It aims to promote whole of government approaches to sustainable development. Despite its prominence in development cooperation discussions, many national development professionals or stakeholders have not heard of PCD, indicating that its effectiveness is significantly limited. This article contends that the impact of PCD has not been maximized because it has been presented as a political objective or a policy tool by multilateral organizations and their member states. Instead, the article argues that PCD should be implemented as a methodology that can be adopted by domestic government and non-governmental actors alike, in order to understand trade-offs and co-benefits within and between policy sectors, thus promoting a participative approach. I-GAMMA is a research project in Mexico that examines data-driven public policy in order to promote PCD. It is based on in-depth reviews of policy documents and interviews with development actors. It is committed to open data, evidence-based policymaking, and collaborative dialogue between academics, government officials, and representatives of civil society organizations in sustainable development discussions. In the results section of this article, the project proposes participative PCD as a methodology for policy analysis through which a plurality of actors can identify mechanisms that either reinforce or undermine sustainable development strategies. This section then applies the methodology to the governance of protected natural areas in Mexico. The discussion section and the conclusions highlight the relevance of this approach for participative policymaking in sustainable development.
\end{abstract}

Keywords: policy coherence for development; protected natural areas; public policy; social participation; sustainable development; Sustainable Development Goals; Mexico

\section{Introduction}

Policy Coherence for Development (PCD) is an instrument established by the global development cooperation community for the purpose of promoting development through international organizations and their member states. It is a policy framework aimed at identifying interactions between different sectors that either undermine or reinforce development policy objectives. PCD was first defined in the 1990s as 'working to ensure that the objectives and results of a government's development policy are not undermined by other policies of that same government which impact on developing countries 
and that these other policies support development objectives where feasible' [1] (p. 28). In this way, PCD was conceived as a political statement that justified the prioritization of development agendas amongst other policy priorities, such as foreign policy, agriculture, trade, finance, and security [2].

Today, the context surrounding PCD has evolved [3,4] The establishment of the 2030 Sustainable Development Agenda has prioritized policy interactions as much as policy implementation in the field of development cooperation [5,6]. Moreover, strategic partnerships adopted within the framework of the 2030 Sustainable Development Agenda have introduced further complexity into development policymaking [7]. For these reasons (amongst others), PCD has moved from the margins to the forefront of sustainable development debates, and it has become a pillar of the 2030 agenda [8]. The definition of PCD has broadened as well. According to the newest OECD definition, PCD is "an approach to integrate the dimensions of sustainable development throughout domestic and international policy-making. Its objectives in the context of the 2030 Agenda are to advance the integrated implementation of the 2030 Agenda by: (i) Fostering synergies and maximizing benefits across economic, social and environmental policy areas, (ii) balancing domestic policy objectives with internationally recognized sustainable development goals, and (iii) addressing the transboundary and long-term impacts of policies, including those likely to affect developing countries" [9].

While these shifts have certainly refocused PCD towards sustainability and reinforced its importance as a decision-making mechanism in the 2030 Agenda (for both international organizations and governments), they have also reinforced the institutional character of policy coherence for development. PCD remains a policy framework that is implemented by governments as policy integration and participatory approaches have not yet been fully incorporated into this development policy approach [10]. This article addresses these concerns by re-orienting PCD as a methodology that can be utilized by a plurality of stakeholders in order to understand interactions between policy sectors, levels of government, and development actors. It reflects research currently undertaken by the I-GAMMA research program, based in the Instituto de Ecología (INECOL), Mexico. This collaborative research project carried out by a team of researchers based in thirteen different institutes and government agencies is committed to promoting evidence-based decision-making in Mexican sustainable development policy, open data and citizen participation in policymaking processes [11]. The project's objective is to provide citizens with accurate, accessible, and understandable information about the state of sustainable development in Mexico as well as fact-based analysis of environmental policymaking [12]. The project also provides training for stakeholders in sustainable development discussions and outreach through community action programs [11].

PCD As an Objective, a Tool, or a Methodology?

Despite its emerging prominence in global affairs, the potential impact of PCD on development outcomes has been limited. While most observers make reference to the OECD's definition presented above, no universally accepted definition, measure or scale of "coherence for development" exists [13]. Policy coherence for development is often misunderstood, even by development professionals. During a 2019 exchange with fifteen African representatives of supranational organizations or national governments, all of whom work in international development, it emerged that none of them had heard of PCD, despite its prominence in the 2030 Sustainable Development Agenda [14]. Simply put, this concept has not been operationalized for those who implement development policies on the ground. This ambiguity limits its utility and effectiveness. In fact, the role of PCD in development policymaking has not been clear.

While the United Nations (UN), EU, and the OECD have championed PCD internationally, significant criticisms of its implementation remain prominent. First, scholars such as Siitonen [6] have argued that the implementation of PCD by supranational organizations has been limited to their own policies or those of their own member states. In doing so, PCD has not been employed to detect incoherences that exist in parts of the world where development occurs, nor has it been applied to donor-recipient relationships. Moreover, because PCD has been implemented in a donor-centric 
way, Thede [15] contends that it actually reinforces global inequalities by highlighting the differences between aid donors and aid recipients. Similarly, Koff and Maganda [16] and Häbel [17] have shown how supranational organizations, such as the European Union, have employed PCD in order to improve the efficiency of their programs at the expense of normative change and global equity. Finally, Carbone and Keijzer [18] and Larsson [19] have shown how PCD has been pursued through institutional reform more than policy implementation. Through this approach, PCD has been promoted more as a political end by international organizations and less as a means to achieve sustainability. In this regard, PCD has been promoted as a political objective.

In pursuing this objective, international organizations and governments have outlined implementation guidelines for PCD. These approaches propose PCD as a tool to promote development objectives. For example, the OECD has introduced "building blocks" for policy coherence for development The OECD's strategy highlights three distinct phases: Setting and prioritizing objectives, coordinating policy and its implementation and monitoring, analysis and reporting [20]. In reference to the Sustainable Development Agenda, the OECD has proposed eight building blocks for implementation, which are: (1) Political commitment and leadership, (2) policy integration, (3) long-term vision and planning horizons, (4) analysis and assessments of potential policy effects, (5) policy and institutional coordination, (6) subnational and local involvement, (7) stakeholder engagement, and (8) monitoring and reporting [21]. The OECD's commitment to PCD is to be applauded. However, the systemic impact of its efforts on policy coherence has been muted in comparison to its importance in ethical discussions in the global arena because these guidelines represent a general policy approach rather than a precise decision-making tool. Building blocks are generalized non-binding policy guidelines more than tools, which are precise instruments for policy implementation and program operationalization. The OECD's PCD approach is useful because it outlines steps for the achievement of PCD. However, unfortunately, it does not offer a precise method for understanding how policy and stakeholder interactions contribute to or detract from specific development objectives.

The European Union's initiatives in the field of PCD have demonstrated similar characteristics. The 2017 European Consensus on Development, which outlines the EU's strategies for implementing the Sustainable Development Goals (SDG's) highlights the need for a "whole of government" approach and coordination efforts at all levels in order to minimize potentially destructive impacts of EU policies on developing countries and EU development cooperation programs [22]. Once again, this represents a general guideline more than a precise tool. For this reason, the literature on PCD has been critical of its implementation and lack of policy impacts $[16-18,23]$. These studies recognize a need for innovation in the way PCD is conceptualized in relation to governance.

In response, the I-GAMMA program attempts to innovate our understanding of PCD by re-orienting it away from its current uses as a political objective and a supposed policy tool. Instead, I-GAMMA proposes PCD as a methodology through which development policy can be analyzed by a plurality of actors in order to understand its impacts on communities where development takes place. It promotes "participatory PCD." There are two important differences between this approach and those described above. First, I-GAMMA takes a bottom-up view of development in which policy methodologies like PCD need to be appropriated and legitimized by local communities. The traditionally donor-centric use of PCD has actually limited its impact in many parts of the world, where it is viewed as part of the agenda of international organizations [15]. I-GAMMA proposes PCD as a method for understanding the coherence of development policies in dialogue with local communities, which define development objectives. In doing so, it actively attempts to shed the eurocentricity associated with PCD [12].

Second, the employment of PCD as a methodology attempts to make this concept user-friendly to public officials and stakeholders at all levels of governance. The methodology is not aimed at generally criticizing policies as inadequate or inefficient. Instead, it attempts to identify specific points of "(in)coherence" within and between policies where decision-makers can intervene in order to 
strengthen sustainable development policy frameworks. In doing so, the methodology addresses the different stages of the policy cycle (see Figure 1). The methodology proposed below assesses the design, legitimization, implementation, and monitoring/evaluation of policies in relation to sustainable development in such a way that it can promote discussions amongst a plurality of stakeholders by providing a common analytical framework that is not context-specific.

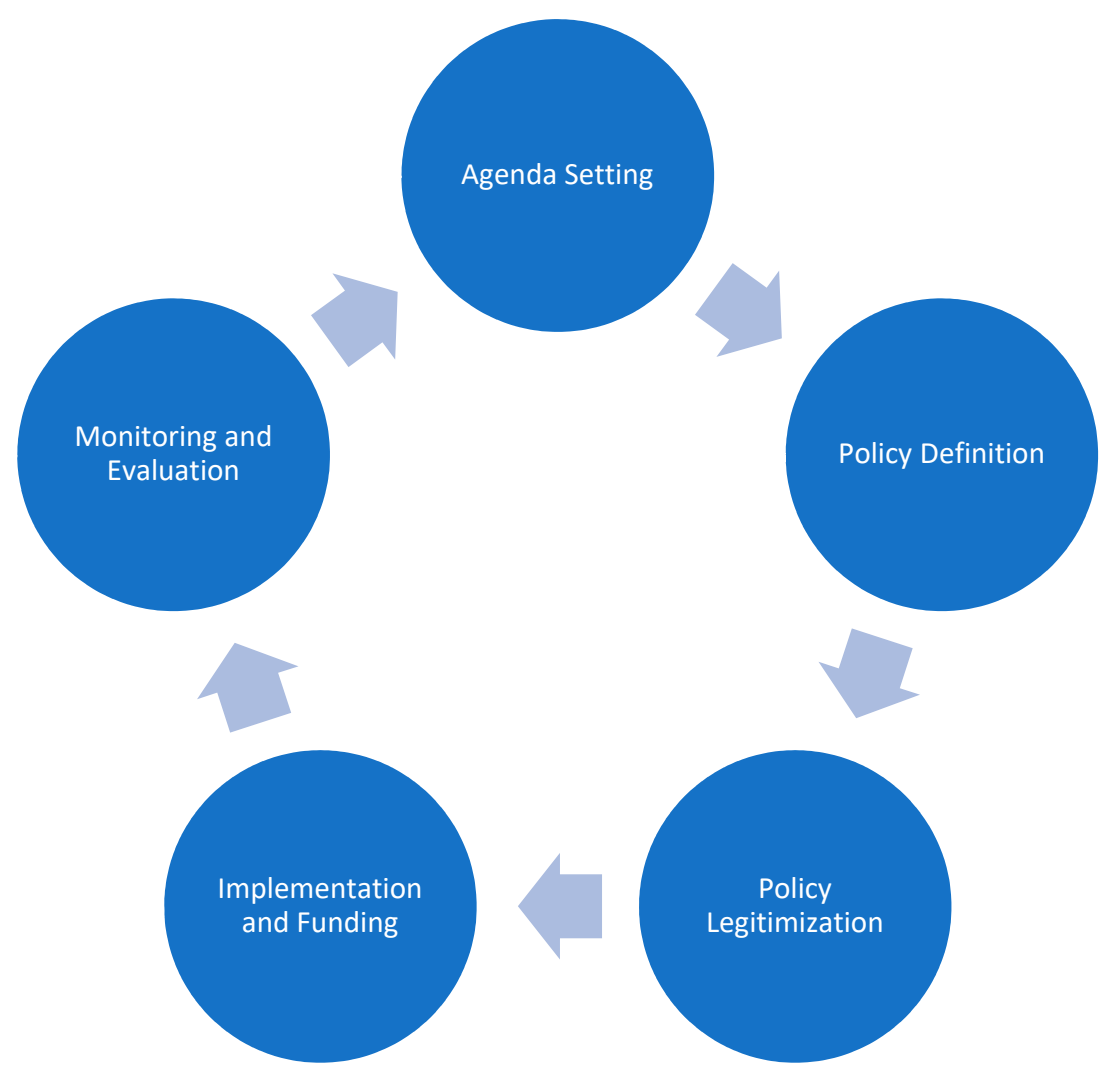

Figure 1. Stages of the policy cycle. Source: Figure drawn by authors.

\section{Materials and Methods}

\subsection{Research Design}

Mexico can be considered a representative case for the study of PCD implementation because, like many emerging economies, the country is characterized by numerous development paradoxes. In terms of sustainable development governance, the country is very supportive of international norms related to human rights, environmental conventions, etc. Each international treaty signed and ratified in Mexico is legally part of constitutional law. Within this context, Mexico has formally implemented PCD in its national development plans as a policy objective. In its 2018 presentation of country profiles on the implementation of PCD amongst its member states, the OECD notes that "An explicit commitment of the State towards the 2030 Agenda, backed by an implementation strategy, provides the basis for aligning efforts at federal, state and municipal levels" [24] (p. 25). The report specifically applauds Mexico for two commitments: (1) Leadership at the highest level is helping to lay institutional foundations to ensure that commitment towards the 2030 Agenda transcends government administrations and (2) national planning and budgetary processes provide essential tools for policy integration and coherence [24] (p. 26).

Within this formal context, however, implementation of PCD has been problematic due to unresolved governance issues, such as lagging accountability, the weak rule of law and a dearth of transparency (according to 22 out 23 interviews with government officials and stakeholders). Mexico is ranked 57 out of 129 countries analyzed through the Bertelsmann Transformation Index (BTI) 
with an overall score of 6.23 out of 10 . The index measures national performance in three sectors, political transformations towards democracy, economic transformations towards market economies and governance, through analysis of sixteen indicators. According to the BTI, Mexico's weakest sector is governance (5.17), and its lowest indicators are the rule of law, resource efficiency, and sustainability. Consequently, Mexico's legal commitments to sustainable development are generally accompanied by implementation difficulties [25].

These paradoxes are reflected in Mexican sustainability statistics as well. For example, Mexico is a model of economic growth as the gross domestic product (GDP) has increased from USD 13.04 billion in 1960 to USD 527.8 billion in 1994 to USD 1.221 trillion in 2018 [26]. Despite this increased wealth, social inequalities and poverty remain prominent as Mexico has a GINI Index of $45.9 \%$ in 2018 and a multidimensional poverty rate of 43.6\% [27]. Environmentally, Mexico is the fifth most biodiverse country in the world, yet only ranked 72 in the Environmental Performance Index [28]. These paradoxes represent the challenges that $\mathrm{PCD}$ is supposed to address.

\subsection{Data Collection}

PCD Research in the I-GAMMA project is based on the examination of key policy documents at the national and state levels (Veracruz and Aguascalientes) and interviews with stakeholders. Veracruz and Aguascalientes are co-sponsors of the I-GAMMA project due to their funding provided within the context of the FORDECYT call for applications from the Mexican Science Council (CONACYT). They also represent most different cases because Aguascalientes is a small, stable, and economically wealthy state which has been recognized for good governance, whereas Veracruz is a larger and poorer state where administrations have been accused of significant corruption. In terms of policy documents, I-GAMMA has compiled an exhaustive list of approximately one hundred laws, regulations, programs, plans, norms and directives related to sustainable development in order to analyze the existing legal corpus in Mexico. The first step in this review is the creation of a benchmark for sustainability, which provides the reference for PCD analysis. Specifically, this approach examines the definition of sustainable development in Mexico's development plans, which outline the country's commitment to and operationalization of the Sustainable Development Goals. This is explained in detail in the "Results" section below. All documents were reviewed in detail by the research team. Members searched for explicit cross-referencing, common terminology, and repeated policy frameworks. In cases of cross-referencing, common terminology, or repeated policy frameworks, the team recognized the presence of normative PCD. When documents omitted important information, redefined terminology, or proposed different implementation frameworks, policy incoherences were recognized. These normative coherences/incoherences were then utilized as the bases for the more elaborate examination of PCD presented below.

In addition to a review of pertinent documents, I-GAMMA includes interviews with stakeholders at different levels of governance. The first set of interviews was conducted with 18 federal government officials, five representatives of national environmental non-governmental organizations (NGOs), and five academic experts. Eight more interviews were conducted with local officials, authorities governing protected natural areas, and academic experts on sustainable development in the Mexican State of Veracruz. All interviewees were presented with a description of the research project and voluntary informed consent forms before the interviews were conducted. This article does not quote interviews directly in order to protect interviewees' anonymity, as explicitly indicated in the informed consent forms.

\section{Results: Four Methodological Steps toward PCD and Their Application to Protected Natural Areas (PNAs)}

This article aims to redefine how PCD is operationalized in order to increase its relevance and impact in sustainability discussions, especially in national and sub-national contexts where policies impact communities. For this reason, this section presents the methodology employed by the I-GAMMA 
project in order to show how it has re-conceived the notion of PCD. The methodology and its relevance for the conceptualization of PCD is the intended contribution of this publication. This section outlines the steps taken in I-GAMMA to operationalize PCD, and it applies them to the analysis of PNA governance in Mexico.

\subsection{Step 1: Definition of Sustainable Development through Establishment of Dimensions}

As stated above, PCD Research in the I-GAMMA project is based on the examination of key policy documents. These include laws, regulations, programs, plans, norms, and directives. The first step in this review is the creation of a benchmark, which will provide the reference for PCD analysis. Specifically, this approach examines the definition of sustainable development, which shall be adopted as the objective for policy coherence (the " $D$ " in PCD) [29].

In order to understand the normative bases for coherence, the I-GAMMA project begins with text mining through the identification of keywords grouped in four dimensions of sustainable development (economic, social, security, and environmental). The first three dimensions are widely recognized. Even though many approaches to sustainability do not explicitly include security, this dimension is recognized in the literature [30,31], and it is a vital element of sustainable development in Mexico where violence remains a major challenge to sustainability. Through text mining, we can identify the keywords that are most present in sustainable development laws/regulations/strategies and group them by dimension. For example, Table 1 presents common elements of sustainable development strategies that are related to specific dimensions.

Table 1. Selected Keywords by Dimensions of Sustainable Development.

\begin{tabular}{cccc}
\hline Economic & Social & Security & Environmental \\
\hline - Competitiveness & - Participation & - Security & - Biodiversity \\
- Productivity & - Human rights & - Peace & - Ecosystem integrity \\
- Globalization & - Social Equity & - Combat violence & - Conservation \\
- Economic viability & - Poverty & - Impunity & - Natural resources \\
- Economic promotion & - Equality & - Rule of law & - Water \\
- Modernization & - Gender & - Anti-corruption & - Forests \\
- Commerce & - Youth & - War against drugs & - Pollution \\
- Business & - Inclusion & - Combat human trafficking & - Climate change \\
- Financial investments & - Cohesion & - Homicides & - Energy \\
- Infrastructure & - Solidarity & - Kidnappings & - Resilience \\
- Consumption & - Food safety & & - Restoration \\
- Innovation & - Rural development & & - Sustainability \\
- Knowledge Sharing & - Urban transformations & & \\
& - Education & & \\
\hline
\end{tabular}

Source: Table compiled by authors.

By identifying keywords in policy and legal documents and organizing them by dimension, the project aims to understand which dimensions are prioritized in national/sub-national sustainable development strategies. I-GAMMA pursues the categorization of sustainable development policies through qualitative reviews of texts, as described above. This approach provides a means for comparison between levels of governance and between research cases. Moreover, categorizing policy content in this way highlights benchmarks for PCD analysis because this illustrates the prioritization of dimensions of sustainability, thus representing operationalized policy definitions of sustainable development. This approach allows I-GAMMA to address two issues: (1) It permits project researchers to analyze the appropriateness of specific policy definitions of sustainable development (i.e., how well they address broad definitions of sustainability) and (2) it provides the normative benchmark to which all policy evaluation is compared. Once the operationalized concept of sustainable development has been established, the next step under this approach is data collection, which is explained in step two. 


\subsection{Step 2. Data Collection: Examination of Sustainable Development Policies Based on Normative} Foundations, Institutionalization, Operationalization and Funding

According to this methodology, data need to be organized around the different steps in the policy cycle presented above. It is important to understand the strengths and weaknesses of policies based on definition, legitimization, implementation, monitoring, and evaluation. For this reason, data collection on sustainable development is organized around four types of information: (1) "Normative" which includes the definition of sustainable development and how it is codified in legal and policy frameworks, (2) "institutional" which addresses the governance structures established around specific laws/policies, (3) "operational" which includes program and project guidelines in order to examine how sustainable development is implemented, monitored and evaluated and (4) "financial" which focuses on funding as well as payment structures, rules, and calendars (see Table 2). Understanding of institutionalization, operationalization, and funding of sustainable development strategies is based on the examination of policy documents as well as program and project descriptions and interviews carried out by the research team with project participants and local stakeholders.

\subsection{Step 3: Identify Categories of Coherences for Sustainable Development}

Once data have been collected, they need to be organized within the framework of policy coherence for development. As stated above, PCD has been traditionally viewed as an objective or tool. However, the name "policy coherence for development" is misleading because various types of (in)coherences for development exist in policymaking. This has been recognized by much of the research in this field $[32,33]$. This research recognizes the heterogeneous nature of public policies related to sustainable development and integrates this approach into the proposal of PCD as a policy methodology. In doing so, it builds on existing studies. Table 3 presents the different dimensions of (in)coherence for sustainable development that guide I-GAMMA.

These PCD typologies represent both internal and external dimensions of sustainable development policy frameworks (see Figure 2 by Koff and Maganda). The internal dimensions refer to (in)coherences that are inherent to specific sustainable development policies, such as water governance, management of protected natural areas, climate change mitigation, etc. They focus on elements within policy frameworks. The external dimensions address (in)coherences between specific policies, such as those listed here and other policy arenas, levels of government or actors in policy networks. They examine the interaction between policy frameworks.

\subsection{Step 4: Model Policy Coherence for Development for each Category}

The final step in I-GAMMA analysis of policy (in)coherence for development entails addressing the complexities of PCD. If PCD is, in fact, to be useful as a methodology, then "coherence" and "incoherence" should not be viewed as absolute categories. Policies cannot be viewed simply as coherent with sustainable development or incoherent with sustainability. Instead, PCD should aim to highlight types of interactions that represent levels of (in)coherences. 
Table 2. Data collection for research on types of coherences for sustainable development.

\begin{tabular}{|c|c|c|c|c|}
\hline & Normative & Institutional & Operational & Financial \\
\hline Horizontal & $\begin{array}{l}\text { Compare laws, regulations, } \\
\text { programs, plans across sectors } \\
\text { within federal and specific state } \\
\text { contexts (examination of } \\
\text { keywords by dimension) }\end{array}$ & $\begin{array}{l}\text { Identification of institutional actors } \\
\text { in sustainable development across } \\
\text { sectors and analysis of their } \\
\text { relationships through policy } \\
\text { documents and interviews }\end{array}$ & $\begin{array}{c}\text { Analysis of PCD at the program/planning } \\
\text { level through examination of interactions } \\
\text { and implementation } \\
\text { (formal/informal/financial relationships) } \\
\text { across policy sectors: Policy documents } \\
\text { and interviews }\end{array}$ & $\begin{array}{l}\text { Analysis of PCD through } \\
\text { examination of policy funding and } \\
\text { subsidies across sectors by } \\
\text { dimension: Policy documents and } \\
\text { interviews }\end{array}$ \\
\hline Vertical & $\begin{array}{l}\text { Compare federal and state laws } \\
\text { to regulations, programs, plans } \\
\text { within sectors (examination of } \\
\text { keywords by dimension) }\end{array}$ & $\begin{array}{l}\text { Identification of institutional actors } \\
\text { in sustainable development at } \\
\text { federal, state, and local levels and } \\
\text { analysis of their relationships } \\
\text { through policy documents and } \\
\text { interviews }\end{array}$ & $\begin{array}{c}\text { Analysis of PCD at the program/planning } \\
\text { level through examination of interactions } \\
\text { and implementation } \\
\text { (formal/informal/financial relationships) } \\
\text { within policy sectors at different levels of } \\
\text { government (by dimension): Policy } \\
\text { documents and interviews }\end{array}$ & $\begin{array}{l}\text { Analysis of PCD through } \\
\text { examination of policy funding and } \\
\text { subsidies within sectors comparing } \\
\text { different levels of government by } \\
\text { dimension: Policy documents and } \\
\text { interviews }\end{array}$ \\
\hline Inter-donor & $\begin{array}{l}\text { Compare policy objectives of } \\
\text { different donors (examination of } \\
\text { keywords by dimension) }\end{array}$ & $\begin{array}{c}\text { Identification of international actors } \\
\text { in sustainable development and } \\
\text { analysis of their relationship to } \\
\text { federal, state, and local actors } \\
\text { through policy documents and } \\
\text { interviews }\end{array}$ & $\begin{array}{c}\text { Analysis of PCD at the program/planning } \\
\text { level through examination of interactions } \\
\text { and implementation } \\
\text { (formal/informal/financial relationships) } \\
\text { amongst donors within specific policy } \\
\text { sectors (by dimension): Policy } \\
\text { documents and interviews }\end{array}$ & $\begin{array}{l}\text { Analysis of PCD through } \\
\text { examination of policy funding and } \\
\text { subsidies from different donors by } \\
\text { dimension: Policy documents and } \\
\text { interviews }\end{array}$ \\
\hline Internal & N.A. & $\begin{array}{l}\text { Analysis of institutional rules and } \\
\text { regulations of administration of } \\
\text { sustainable development strategies } \\
\text { by dimension (policy documents } \\
\text { and interviews) }\end{array}$ & $\begin{array}{c}\text { Analysis of PCD at the program/planning } \\
\text { level through examination of interactions } \\
\text { and implementation } \\
\text { (formal/informal/financial relationships) } \\
\text { within sustainable development } \\
\text { strategies: Policy documents and } \\
\text { interviews }\end{array}$ & $\begin{array}{l}\text { Analysis of PCD through } \\
\text { examination of structure and rules } \\
\text { of policy funding and subsidies by } \\
\text { dimension: Policy documents and } \\
\text { interviews }\end{array}$ \\
\hline Inter-organizational & $\begin{array}{l}\text { Compare policy objectives of } \\
\text { government and NGOs } \\
\text { (examination of keywords by } \\
\text { dimension) }\end{array}$ & $\begin{array}{l}\text { Identification of non-governmental } \\
\text { actors in specific sustainable } \\
\text { development contexts and analysis } \\
\text { of their relationship to federal, state, } \\
\text { and local actors through policy } \\
\text { documents and interviews }\end{array}$ & $\begin{array}{c}\text { Analysis of PCD at the program/planning } \\
\text { level through examination of interactions } \\
\text { and implementation } \\
\text { (formal/informal/financial relationships) } \\
\text { of programs within non-governmental } \\
\text { sector and between government and } \\
\text { NGOs }\end{array}$ & $\begin{array}{l}\text { Analysis of PCD through } \\
\text { examination of funding and } \\
\text { subsidies within Non-governmental } \\
\text { sector and between NGOs and } \\
\text { government by dimension: Policy } \\
\text { documents and interviews }\end{array}$ \\
\hline
\end{tabular}


Table 2. Cont.

\begin{tabular}{|c|c|c|c|c|}
\hline & Normative & Institutional & Operational & Financial \\
\hline Multilateral & $\begin{array}{l}\text { Compare policy objectives of } \\
\text { international organizations } \\
\text { (examination of keywords by } \\
\text { dimension) }\end{array}$ & $\begin{array}{c}\text { Identification of international actors } \\
\text { in sustainable development and } \\
\text { analysis of their relationship to } \\
\text { federal, state, and local actors } \\
\text { through policy documents and } \\
\text { interviews }\end{array}$ & N.A. & N.A. \\
\hline Financial & $\begin{array}{l}\text { Compare weight of funding for } \\
\text { each dimension of sustainability }\end{array}$ & $\begin{array}{l}\text { Analysis of institutional rules and } \\
\text { regulations for funding of } \\
\text { sustainable development strategies } \\
\text { by dimension (policy documents } \\
\text { and interviews) }\end{array}$ & $\begin{array}{c}\text { Analysis of PCD at the program/planning } \\
\text { level through examination of financial } \\
\text { interactions (formal/informal/financial } \\
\text { relationships) }\end{array}$ & $\begin{array}{l}\text { Analysis of PCD through } \\
\text { examination of policy funding and } \\
\text { subsidies by dimension: Policy } \\
\text { documents and interviews }\end{array}$ \\
\hline Normative & $\begin{array}{l}\text { Text mining analysis of } \\
\text { keywords by dimension using } \\
\text { categories above }\end{array}$ & $\begin{array}{l}\text { Analysis of Institutionalization of } \\
\text { norms through policy documents }\end{array}$ & $\begin{array}{c}\text { Analysis of the operationalization of } \\
\text { norms through projects: Policy } \\
\text { documents and interviews focused on } \\
\text { implementation }\end{array}$ & $\begin{array}{c}\text { Analysis of the operationalization } \\
\text { of norms through funding of } \\
\text { projects: Policy documents and } \\
\text { interviews }\end{array}$ \\
\hline
\end{tabular}

Source: Table compiled by authors. N.A. = Not applicable. 
Table 3. Typologies of Policy (In)coherence for Development [33].

\begin{tabular}{|c|c|}
\hline Typology of (In)coherence & Definition \\
\hline Horizontal (in)coherence & (In)coherence between development and non-development policies \\
\hline Vertical (in)coherence & $\begin{array}{c}\text { (In)coherence between policies of regional organizations, member states, } \\
\text { municipalities }\end{array}$ \\
\hline Inter-donor (in)coherence & (In)coherence between development policies/projects of different donors \\
\hline Internal (in)coherence & $\begin{array}{l}\text { (In)consistencies between the objectives and means of a given policy } \\
\text { (i.e., measurement techniques, monitoring) }\end{array}$ \\
\hline Inter-organisational (in)coherence & $\begin{array}{l}\text { (In)coherence between the development policies of a country's } \\
\text { government and civil society organizations }\end{array}$ \\
\hline Multilateral (in)coherence & $\begin{array}{l}\text { (In)compatibility between the development goals and procedural norms } \\
\text { of international organizations such as the EU, OECD, the UN, and the } \\
\text { international financial institutions }\end{array}$ \\
\hline Financial (in)coherence & $\begin{array}{l}\text { (In)coherence between the structure of development funding and policy } \\
\text { objectives }\end{array}$ \\
\hline Normative (in)coherence & $\begin{array}{c}\text { (In)coherence between policy strategies in development and } \\
\text { non-development policy arenas and core values of liberal democratic } \\
\text { societies }\end{array}$ \\
\hline
\end{tabular}

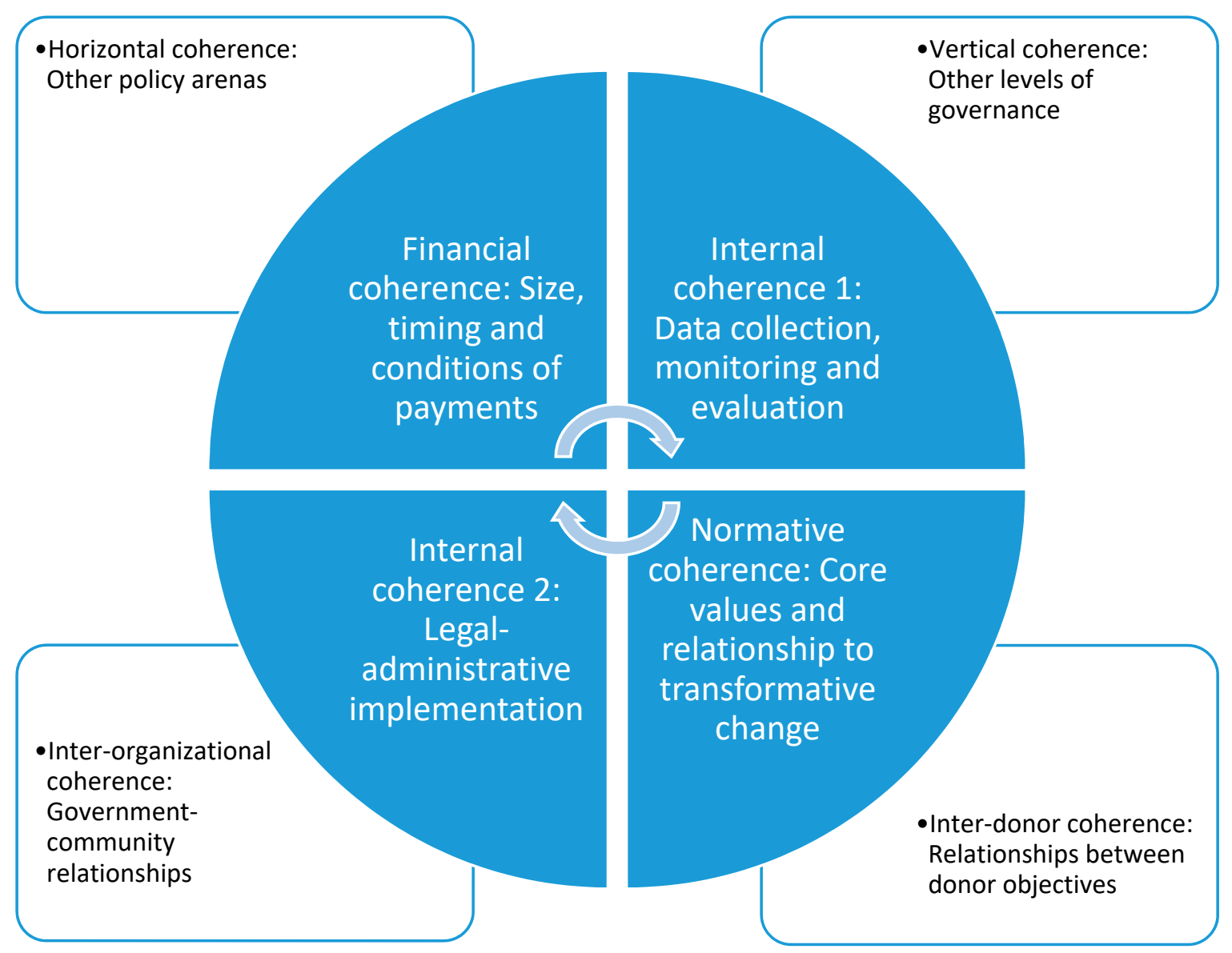

Figure 2. PCD as a methodological model for policy analysis [34] (p. 5). 
Table 4. Horizontal Coherence for Development [5].

\begin{tabular}{|c|c|c|c|}
\hline Interaction & Name & Explanation & Example \\
\hline+3 & Indivisible & $\begin{array}{l}\text { Inextricably linked to } \\
\text { the achievement of } \\
\text { another goal. }\end{array}$ & $\begin{array}{l}\text { Ending all forms of discrimination against women } \\
\text { and girls is indivisible from ensuring women's full } \\
\text { and effective participation and equal opportunities } \\
\text { for leadership. }\end{array}$ \\
\hline+2 & Reinforcing & $\begin{array}{l}\text { Aids the achievement } \\
\text { of another goal. }\end{array}$ & $\begin{array}{c}\text { Providing access to electricity reinforces } \\
\text { water-pumping and irrigation systems. } \\
\text { Strengthening the capacity to adapt to } \\
\text { climate-related hazards reduces losses caused by } \\
\text { disasters. }\end{array}$ \\
\hline+1 & Enabling & $\begin{array}{l}\text { Creates conditions } \\
\text { that further another } \\
\text { goal. }\end{array}$ & $\begin{array}{l}\text { Providing electricity access in rural homes enables } \\
\text { education because it makes it possible to do } \\
\text { homework at night with electric lighting. }\end{array}$ \\
\hline 0 & Consistent & $\begin{array}{l}\text { No significant } \\
\text { positive or negative } \\
\text { interactions. }\end{array}$ & $\begin{array}{l}\text { Ensuring education for all does not interact } \\
\text { significantly with infrastructure development or } \\
\text { conservation of ocean ecosystems. }\end{array}$ \\
\hline-1 & Constraining & $\begin{array}{l}\text { Limits options on } \\
\text { another goal. }\end{array}$ & $\begin{array}{l}\text { Improved water efficiency can constrain } \\
\text { agricultural irrigation. Reducing climate change } \\
\text { can constrain the options for energy access. }\end{array}$ \\
\hline-2 & Counteracting & $\begin{array}{l}\text { Clashes with another } \\
\text { goal. }\end{array}$ & $\begin{array}{l}\text { Boosting consumption for growth can counteract } \\
\text { waste reduction and climate mitigation. }\end{array}$ \\
\hline-3 & Canceling & $\begin{array}{l}\text { Makes it impossible } \\
\text { to reach another goal. }\end{array}$ & $\begin{array}{l}\text { Fully ensuring public transparency and democratic } \\
\text { accountability cannot be combined with } \\
\text { national-security goals. Full protection of natural } \\
\text { reserves excludes public access for recreation. }\end{array}$ \\
\hline
\end{tabular}

In order to carry out this task, a starting point is a recently published study by Nilssen et al., (2018) on the SDG's. This group of scholars argues that, "Pursuing integrated research and decision-making to advance action on the sustainable development goals (SDGs) fundamentally depends on understanding interactions between the SDGs, both negative ones ("trade-offs") and positive ones ("co-benefits")" [5] (p. 1). In order to accomplish this goal, these authors propose typologies and characterizations similar to those described above. Their innovative research presents scales that characterize different types of interactions between the SDG's as the basis for a Knowledge Platform on SDG interaction. This research is the starting point for I-GAMMA's analysis of domestic PCD which also aims to establish a participative knowledge platform/resource center on domestic implementation of sustainable development in countries such as Mexico. What has been identified as horizontal (in)coherence for development most closely resembles the research on SDG interactions presented by Nilssen et al. [5]. The implementation of this framework is established in Table 4, which focuses on horizontal (in)coherences presenting (in)coherence scales between policy sectors. It indicates values that operationalize how well integrated/harmonized/coordinated policy sectors are in the positive sense (coherence) and values that operationalize how policy sectors undermine each other through a lack of coordination/harmonization or the establishment of conflicting objectives. The table reflects both actor-driven and system-driven (in)coherences as well as intentional and unintentional (in)coherences.

Based on the categories presented in Table 3 above, Tables A1-A6 (see Appendix A) then present the criteria for implementing this framework for the other types of (in)coherences. These tables have been compiled by the authors based on the scale presented in Table 4. A scale has not been presented for multilateral coherence for development because it is not overtly applicable to the domestic arena. Moreover, the activities of multilateral organizations in domestic policy frameworks overlap with vertical coherence for development, inter-donor coherence for development, and financial coherence for development. The norms which multilateral organizations provide as references to domestic policymakers are part of normative coherence for development. For example, 22 out of 23 interviewees 
at the national and state levels confirmed that international norms, such as the goals and targets included in the 2030 Sustainable Development Agenda influence their work on a daily basis by providing normative guidelines for the definition of domestic policy goals and targets [35]. The SDGs provide benchmarks against which domestic policy can be compared, thus promoting citizen-centered frameworks by contributing to accountability.

The application of these scales to the analysis of sustainable development governance aims to identify specific mechanisms within and between policy frameworks that reinforce or undermine sustainability. While the scales can provide an overall "coherence score" based on aggregate values, their real value lies in potential comparisons within categories in order to identify the strengths and weaknesses of policy frameworks. This could offer useful information to both governmental and non-governmental stakeholders, which can promote participative approaches to policymaking.

\subsection{Implementation of I-GAMMA Methodology in Protected Natural Areas}

Protected natural areas are defined as "clearly defined geographical spaces, recognized, dedicated and managed, through legal or other effective means, to achieve the long-term conservation of nature with associated ecosystem services and cultural values" [36]. In development terms, protected natural areas present various complexities. They are generally recognized as sustainable responses to uncontrolled globalized economic development that harms natural resources and landscapes and contributes to the socio-economic marginalization of local communities living on these lands [37]. At the same time, the declaration and zoning of protected natural areas restrict opportunities for inhabitants of these areas to utilize natural resources for economic gain, thus raising questions about the economic sustainability of these initiatives [38].

These debates are relevant to Mexico. At the end of 2018, the country had 182 protected natural areas with a total coverage of 908,395.20 square kilometers [39]. The first 39 of these areas were decreed between 1934 and 1940 by President Lazaro Cardenas, who was the first national leader to recognize the importance of conserving Mexico's natural resources [39]. Following his Presidency, however, the commitment to PNAs waned significantly as only seven more areas were decreed by 1976. In fact, the general state of Mexico's natural areas was deteriorating during this period [40].

The history of Mexico's PNAs is linked to the country's economic development. Challenger [39] has documented how most of the above-cited PNAs were defined and zoned in the 1980s and 1990s as a response to the Green Revolution, which industrialized Mexico's agriculture sector as well as the country's integration in the North American Free Trade Agreement [40]. Similarly, Carlos Cortez and Luisa Paré explain how the declaration of PNAs in Southern Mexico accompanied the country's participation in the Plan Puebla Panama (PPP), a macro-investment infrastructure development program for Southern Mexico and Central America that was supported financially by supranational development banks (notably the Inter-American Development Bank) and the United States [41]. While PNAs aimed to mitigate the impact of globalized development on Mexico's natural resources and biodiversity, they also prioritized conservation of nature over local human development in many ways.

This situation is not atypical. In fact, a major question in the study on protected natural areas asks whether these measures can achieve their dual roles by simultaneously promoting the conservation of biological diversity and the economic welfare of local people [37]. This is a timely issue as both of these objectives are prominent in the 2030 Sustainable Development Agenda. For this reason, I-GAMMA selected PNAs as a pilot arena for the implementation of the PCD methodology presented above. It focuses on balanced development strategies that promote both ecological conservation and socio-economic integration.

A first query on which I-GAMMA focused inquired whether the federal and state governments included in this study define their policies on PNAs through the same terms. Following Step 1 from the methodology presented above, an analysis of federal and relevant state policies on PNAs was conducted. This research indicated that each policy has adopted a different normative framework for 
the governance of protected natural areas. Tables 5-7 present the dimensions for PNA management at each level of governance.

Table 5. Dimensions of Sustainability in Mexican Federal Legislation of PNAs.

\begin{tabular}{|c|c|c|c|}
\hline Economic & Social & Security & Environmental \\
\hline \multirow{6}{*}{$\begin{array}{l}\text { I. Protect villages, roads } \\
\text { communication, } \\
\text { industrial facilities, and } \\
\text { agricultural uses, } \\
\text { through forest areas in } \\
\text { mountains where } \\
\text { torrents originate; }\end{array}$} & \multirow{6}{*}{$\begin{array}{l}\text { I. Protect the natural } \\
\text { surroundings of areas, } \\
\text { monuments, and } \\
\text { archaeological, historical, } \\
\text { and artistic vestiges, as } \\
\text { well as tourist areas and } \\
\text { other areas of importance } \\
\text { for recreation, culture, } \\
\text { and national identity and } \\
\text { indigenous peoples. }\end{array}$} & \multirow[t]{6}{*}{-} & $\begin{array}{l}\text { I. Preserve the natural environments of } \\
\text { the different biogeographical and } \\
\text { ecological regions and the most fragile } \\
\text { ecosystems, as well as their functions, to } \\
\text { ensure the balance and continuity of } \\
\text { evolutionary and ecological processes; }\end{array}$ \\
\hline & & & $\begin{array}{l}\text { II. Safeguard the genetic diversity of } \\
\text { wild species on which evolutionary } \\
\text { continuity depends, as well as ensuring } \\
\text { the preservation and sustainable use of } \\
\text { the national territory's biodiversity. }\end{array}$ \\
\hline & & & $\begin{array}{l}\text { III. Protect the hydrological cycle in } \\
\text { basins, as well as the other regions }\end{array}$ \\
\hline & & & $\begin{array}{l}\text { IV. Ensure the preservation and } \\
\text { sustainable use of ecosystems, their } \\
\text { elements, and their functions; }\end{array}$ \\
\hline & & & $\begin{array}{l}\text { V. Provide a conducive field for } \\
\text { scientific research and the study of } \\
\text { ecosystems and their balance; }\end{array}$ \\
\hline & & & $\begin{array}{l}\text { VI. Generate, rescue and disseminate } \\
\text { traditional or new knowledge, practices, } \\
\text { and technologies that allow the } \\
\text { preservation and sustainable use of the } \\
\text { biodiversity of the national territory; }\end{array}$ \\
\hline
\end{tabular}

Source: Table compiled by authors.

Table 6. Dimensions of Sustainability in Veracruz State Legislation of PNAs.

\begin{tabular}{|c|c|c|c|}
\hline Economic & Social & Security & Environmental \\
\hline $\begin{array}{l}\text { I. Programs seek to design economic } \\
\text { instruments and strategies so that } \\
\text { harvesting activities and logging } \\
\text { "are compatible with those of the } \\
\text { community on environmental } \\
\text { protection and sustainable } \\
\text { development". }\end{array}$ & $\begin{array}{l}\text { I. The regulation of human } \\
\text { settlements }\end{array}$ & & $\begin{array}{l}\text { I. Preserve and interconnect } \\
\text { natural environments, safeguard } \\
\text { the genetic diversity of wild } \\
\text { species, achieve sustainable use of } \\
\text { natural resources and improve the } \\
\text { quality of the environment in } \\
\text { population centers and their } \\
\text { surroundings }\end{array}$ \\
\hline $\begin{array}{l}\text { II. In terms of PNAs, the modalities } \\
\text { that mention forestry are "ecological } \\
\text { reserves" and "multifunctional } \\
\text { biological corridors". }\end{array}$ & $\begin{array}{l}\text { II. Governance of } \\
\text { above-ground or } \\
\text { underground facilities, } \\
\text { lines, or pipelines through } \\
\text { human settlements in } \\
\text { PNAs. }\end{array}$ & & $\begin{array}{l}\text { II. Programs of reforestation and } \\
\text { afforestation, for the prevention, } \\
\text { control, and combat of pests, } \\
\text { diseases, and forest fires, the latter } \\
\text { in terms of NOMs (Mexican } \\
\text { legislative norms), and to establish } \\
\text { forest closures when justified in } \\
\text { the modalities for the } \\
\text { management of forest resources } \\
\text { included in PNA legislation. }\end{array}$ \\
\hline
\end{tabular}


Table 6. Cont.

\begin{tabular}{|c|c|c|c|}
\hline Economic & Social & Security & Environmental \\
\hline $\begin{array}{l}\text { III. "Productive activities" with the } \\
\text { inhabitants who live there, are } \\
\text { allowed under both categories as } \\
\text { long as they are compatible with } \\
\text { sustainable management programs } \\
\text { and with the management programs } \\
\text { that are issued. }\end{array}$ & $\begin{array}{l}\text { III. "The creation of } \\
\text { protected natural areas, } \\
\text { and other measures aimed } \\
\text { at the protection of natural } \\
\text { resources in indigenous } \\
\text { territories, must be carried } \\
\text { out through explicit } \\
\text { agreements between the } \\
\text { State and indigenous } \\
\text { peoples and communities } \\
\text { with mediation of the State } \\
\text { Council "(Art. } 71) \text {. }\end{array}$ & & $\begin{array}{l}\text { III. Prohibition of "Dumping } \\
\text { waste [...], in protected natural } \\
\text { areas or private conservation } \\
\text { areas, as well as in any place not } \\
\text { authorized for such purposes". }\end{array}$ \\
\hline
\end{tabular}

IV. Protection of Flora and Fauna

Source: Table compiled by authors.

Table 7. Dimensions of Sustainability in Aguascalientes State Legislation of PNAs.

\begin{tabular}{|c|c|c|c|}
\hline Economic & Social & Security & Environmental \\
\hline
\end{tabular}

II. The Tourism Law of the State of Aguascalientes (POEA, 2007), recognizes the importance of natural landscapes for tourist activities, and in this sense Article 4, which establishes the objectives of the Law, determines that the first of them is, "To regulate tourist activity in the State, promoting the rational use of tourist attractions and resources, conserving and preserving the environment, ecological balance and social harmony for the benefit of the population".

III. PNA legislation regulates "sustainable development of agricultural activity"
II. Guarantee that state

development is comprehensive and sustainable;
II. Prevent environmental imbalance, defined as the "Alteration of interdependent relationships between the natural elements that make up the environment" which negatively affects the existence, transformation, and development of human beings and other living beings"

III. Aguascalientes (POEA,

2000a) contains various provisions in the area of ecological ordering in relation to PNAs, especially Articles 17, 24, and 29 (POEA, 2000a), that deal with the need to coordinate between territorial ordinances that that coincide with PNAs.
III. Conservation, preservation, restoration, and protection of ecosystems and the environment, as well as confronting the prevention of damage to them;

IV. Citizen consultation,

Evaluation, on the state PNA regulations, the State Ecological Planning Program, and other regional planning programs..."

IV. Conserve biological diversity; $[\ldots] "$ 
Table 7. Cont.

\begin{tabular}{|c|c|c|c|}
\hline Economic & Social & Security & Environmental \\
\hline & $\begin{array}{l}\text { V. Coordination of the State } \\
\text { Ecological Planning programs } \\
\text { and Territorial, Urban } \\
\text { Development and Housing } \\
\text { Planning, as well as the other } \\
\text { projects deriving from these } \\
\text { measures (Article 22), }\end{array}$ & - & $\begin{array}{l}\text { V. Define the principles by } \\
\text { which environmental policy in } \\
\text { the State will be formulated, } \\
\text { conducted, and evaluated, as } \\
\text { well as the instruments and } \\
\text { procedures for its } \\
\text { implementation. }\end{array}$ \\
\hline & $\begin{array}{l}\text { VI. Apply, in coordination } \\
\text { with the municipalities and } \\
\text { the federal government, where } \\
\text { appropriate, the necessary } \\
\text { measures, to protect } \\
\text { "don-development" lots or } \\
\text { properties subject to } \\
\text { conservation and restauration, } \\
\text { be they archaeological, } \\
\text { historical, agricultural, mining, } \\
\text { rural, forest, protected natural } \\
\text { areas ..." }\end{array}$ & - & $\begin{array}{l}\text { VI. Establish the powers of the } \\
\text { state and municipal authorities } \\
\text { in conservation, preservation, } \\
\text { restoration, and protection of } \\
\text { ecosystems and the } \\
\text { environment, as well as the } \\
\text { prevention of damage to them; }\end{array}$ \\
\hline & - & - & $\begin{array}{l}\text { VII. Conservation of the forestry } \\
\text { sector, which plays a key role in } \\
\text { establishing the State's Natural } \\
\text { Protected Areas. }\end{array}$ \\
\hline
\end{tabular}

Source: Table compiled by authors.

These tables already provide interesting indications concerning PCD and PNA governance in Mexico. First, security as a dimension of sustainability is absent throughout the normative framework at federal and state levels. This is important because insecurity is an issue for communities living in these areas. For example, Koff and Maganda's analysis of payments for watershed services in Veracruz included mention of local security costs for communities forced to pay for private security on conservation lands in order to prevent criminal activity and illegal logging [34].

Second, these tables illustrate three different normative approaches to the governance of PNAs, indicating significant normative incoherence in Mexican legislation. Federal legislation focuses squarely on the environmental dimension of conservation. The states included in this study both provided a more balanced approach, but Veracruz's framework is more superficial, offering general guidelines, whereas Aguascalientes' legislation provides greater detail and cross-referencing. This is illustrated in Figure 3, which provides a visual representation of each policy's normative approach to PNA governance by dimension. Following step one of the methodological guide above, the figure shows that Aguascalientes promotes the most comprehensive approach to PNA governance, whereas Veracruz's is balanced but limited, and the federal government has designed an unbalanced governance strategy that privileges conservation.

Following the examination of legislative frameworks on PNAs, the research team enacted Step two of the methodology presented above by conducting interviews with government officials, representatives of non-governmental organizations, academic experts on PNA governance and residents. Members of the research team also conducted site visits to PNAs in Veracruz. These interviews and visits focused on policy legitimization, implementation, and evaluation. Specifically, they investigated the role of local communities in decision-making on PNAs, important threats to conservation of PNAs, economic activities in PNAs, and monitoring and evaluation of PNA policies. The interviews allowed respondents to identify seeming coherences/incoherences by themselves and they aimed to clarify and "map" relationships between policymakers and stakeholders around PNAs. 


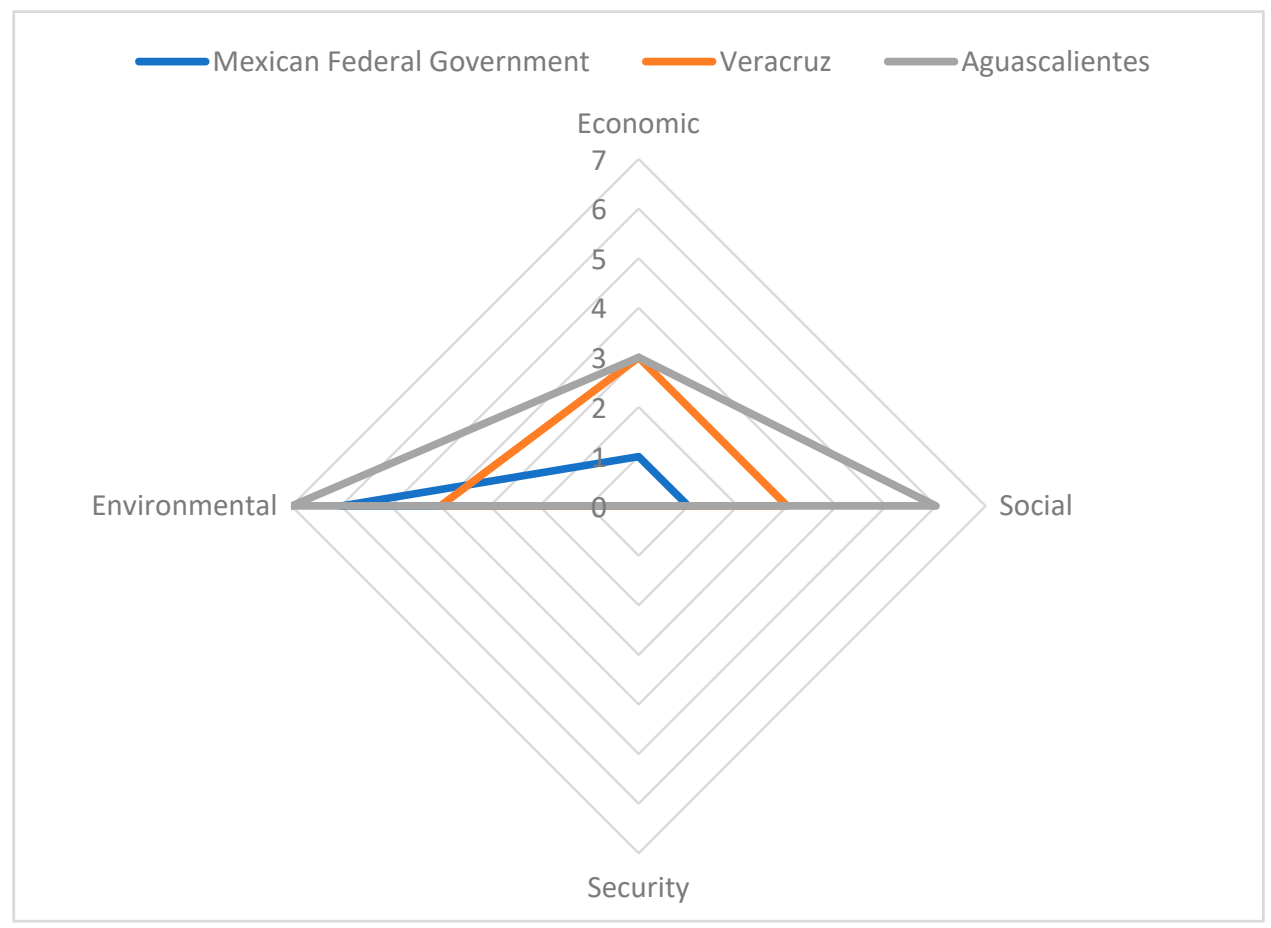

Figure 3. Dimensions of Sustainable Development in PNA Legislation: Mexican Federal Government, Veracruz and Aguascalientes Compared (Source: Figure Drawn by Authors).

The interviews once again uncovered important differences between federal and state management of PNAs, which are highlighted in Figure 4. The figure demonstrates the different types (step three of the methodology) and levels (step four of the methodology) of PCD that exist at the federal and state levels in Mexico. At the federal level, the unbalanced legislation creates important incoherences with other policy arenas (horizontal). Little coherence exists between PNA management and other sectors, such as mining, tourism, energy, etc. Moreover, vertical incoherences exist because of the differences between national and state approaches to PNA governance. On the contrary, legitimization, implementation, and monitoring/evaluation are quite coherent with sustainable development in PNAs at the federal level. Federal officials foster relationships with local communities, NGOs, and ethnic groups, their administrative structures are appropriate for implementation, and the federal government has recently established a system of citizen monitoring and evaluation of PNA management. The only arena where important incoherences exist in relation to policy implementation relates to funding as the federal management of PNAs is characterized by financial and inter-donor incoherences.

State PNA governance in Mexico demonstrates very different characteristics. State sustainable development programs integrate environmental governance and PNA management within general development frameworks. For these reasons, positive horizontal coherence exists, and threats to PNAs do not come from other policy sectors. However, vertical incoherences are especially marked with municipalities. In both Veracruz and Aguascalientes, the biggest threats to PNAs come from urbanization and the application of zoning laws. As cities grow, PNAs are vulnerable to the encroachment of population settlements due to technical loopholes in zoning regulations. Moreover, paradoxically both states neglect citizen participation mechanisms in PNA governance, including citizen monitoring/evaluation. Funding incoherences also characterize state PNA governance in Veracruz and Aguascalientes.

The application of this model highlights the strengths and weaknesses of sustainable development policies for citizens and government officials alike. This is especially important in PNAs where residents are often at odds with government officials due to regulations on economic activities. [42] or seeming injustices perpetrated by external actors [43]. Brenner notes how dissatisfied citizens, 
even those who are marginalized, can organize and follow constant strategies of resistance, including disregard for government regulations, thus undermining the mission of PNAs [42]. In order for PCD to address these situations, stakeholders and government officials must participate in the identification of specific incoherences, and the results of this analysis should inform mutual learning processes on which citizen-government dialogue can be nurtured.

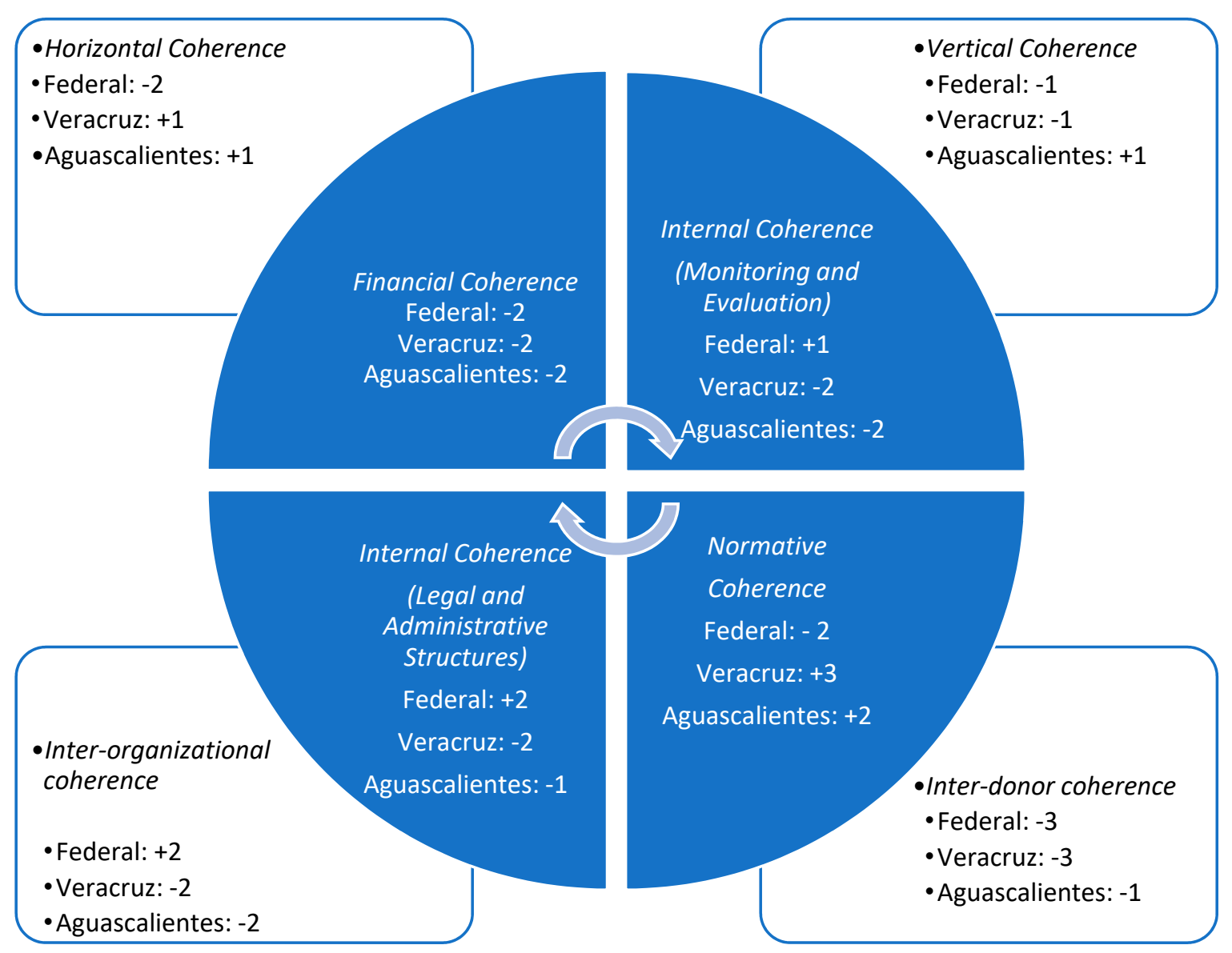

Figure 4. Implementation of the methodological model to the governance of PNAs. Source: Figure drawn by authors.

\section{Discussion: Participative Policymaking in Sustainable Development and PCD}

Transdisciplinary approaches to sustainable development, which include stakeholders in the design of scientific studies, and citizen science, have become integral parts of the research on sustainable development $[44,45]$. These approaches focus on incorporating citizens in the scientific method in ethical ways [46], and in doing so, they view them as more than subjects of scientific research: They are partners. As stated above, I-GAMMA is committed to this general goal [11]. However, this approach implies important challenges. For example, at the beginning of research in 2018, the project team contacted government officials and non-governmental stakeholders in Veracruz State working in different policy sectors, such as trade, finance, security, infrastructure, education, budget, and agriculture in order to conduct interviews on sustainable development. Most public officials refused our interview requests because they considered "sustainability" to be outside their area of work. They suggested that we contact the Secretariat for the Environment. Similarly, researchers contacted residents and non-residents of protected natural areas in 2019 in order to conduct interviews on conditions in PNAs. Many non-residents did not understand the relevance of research on this topic for them.

While development professionals working in international organizations may understand the relevance of inter-sectoral dialogue for sustainability at a macro level, our experiences have shown that 
this is not necessarily the case amongst citizens or sub-national stakeholders. Generally, government officials and non-governmental stakeholders form policy communities that are interest-specific $[17,47]$. For example, the participants in the two policy forums on PCD organized by I-GAMMA admitted that these were the first meetings on sustainability in which they had participated with a plurality of actors from different arenas [48].

This starting point for research on PCD is significant because of the general recognition of the value of participative approaches to sustainable development. For example, the literature on environmental impact assessment has evolved significantly to include analysis of social participation, power inequalities, learning processes, norm diffusion, etc., [49,50]. The notion of Strategic Environmental Assessment (SEA) includes citizen participation in environmental impact assessment from beginning to end of the evaluation process [51]. The research on environmental policy integration (EPI) similarly aims to promote citizen understanding of the interaction between environmental conservation, economic competitiveness, and social protection [52]. Participatory environmental modeling promotes citizen engagement with community-level environmental management [53]. All of these approaches promote citizen ownership of both scientific inquiry at the community level and sustainable development policymaking. Ownership of development processes is a major theme in international development cooperation as it has been institutionalized through the OECD's 2011 Busan Development Principles [54]. However, citizen ownership of development processes in often problematic, especially in emerging states or consolidating democracies [55]. For example, observers of Mexican politics have noted how federal, state, and local administrations have often reversed policies and programs just because they were formulated by the preceding government, thus perpetuating a scenario of discontinuity [56].

This research addresses this situation because it provides a methodological framework, which can be used by government officials or non-governmental stakeholders to examine policy interactions. Rather than dictating PCD to stakeholders, this approach consults them, and it provides a method, which can be appropriated and implemented by citizens for their own purposes. If the PCD community can be open to citizen participation, transformational conflicts will be raised, pursued, and deliberated [57]. In this regard, the research presented in this article aims to extend the research on participatory policymaking by introducing a tool that is accessible and understandable [58]. Jordan and Lenschow rightly contend that EPI is a quasi-constitutional norm in European politics that enjoys widespread commitment at the policy level, but there is limited consensus regarding application and understanding of outcomes [52]. Similarly, SEA is a norm that has not even been adopted in many national legal frameworks for environmental impact assessment [59]. Policy coherence for development is different from these other approaches because it does not seek to integrate different sectors or "mainstream" specific policy goals (such as climate change mitigation). These approaches seek to incorporate development strategies by either diffusing specific development objectives in all policy arenas ("mainstreaming") or identifying common policy objectives to be pursued through shared implementation tools in different sectors ("policy integration"). PCD recognizes the separation of policy sectors. It aims to clarify the relationships between them and identify the mechanisms through which they affect each other [34] with the goal of highlighting specific points of interaction in policy cycles that either reinforce or undermine sustainability. Once identified, citizens and government officials can pinpoint problem areas and mutually reinforce best practice (which can be mainstreaming or policy integration but need not be either) in such a way as to better promote transformative sustainable development from below. The literature on reflexive governance highlights the importance of the human dimension of policymaking in the area of sustainable development $[60,61]$. The approach to PCD presented here can be considered a step in this direction. While the model remains technical in many ways, it does break down the notion of PCD into dimensions in order to simplify the concept for all stakeholders. Moreover, it does not prescribe in the same way that building blocks do (see OECD) [20,21], but it responds to the value judgments of users who can implement the scales for each dimension according to their own criteria and elaborate their own political strategies for the 
implementation of sustainable development. This aims to contribute to the attainment of the SDGs from below.

\section{Conclusions}

Policy coherence for development is meant to be a pillar of the 2030 Sustainable Development Agenda. It has been championed by international organizations such as the UN, EU, and the OECD as a means to promote transformative development. Nonetheless, PCD remains relatively unknown and misunderstood by many development stakeholders on the ground. For example, none of the interviewees contacted for this research in Mexico had previously heard of PCD, let alone implemented it.

These conversations highlight a major problem related to PCD. It is supposed to promote transformative sustainable development, but it remains unknown in the communities where transformation is supposed to take place. Its vertical nature and promotion through international organizations and their member states actually inhibit understanding amongst citizens, and its impact on development processes remains limited. The view of PCD as an objective or a tool has institutionalized it. Therefore, ownership of PCD is a problem.

The I-GAMMA project is addressing this situation through the approach described above. It promotes PCD as a methodology so that stakeholders and citizens can reflect on how policy frameworks interact in their own activity arenas, how to recognize trade-offs and co-benefits, and how to identify policy mechanisms that undermine or reinforce sustainability within their sector of interest and more generally. This can assist with the definition of policy strategies and the facilitation of mobilization. This approach can be applied to specific programs, like payment for watershed services [34] or macro policy frameworks, such as migration [62].

I-GAMMA is committed to open data, collaboration between scientists, government officials, and civil society organizations, evidence-based decision-making, and citizen participation in sustainable development policymaking. The common threads of open data, citizen participation, and institutional transparency are the bases for the project. Ownership of policy approaches, such as PCD should not be restricted to institutions or specialists. Instead, I-GAMMA promotes a participative approach through which citizens can appropriate scientific analysis for their own needs. For this reason, we share this methodology as a foundation for the proposal of participative PCD. We welcome comments on the methodology proposed above, and we hope that scientists and stakeholders from different sectors and world regions can appropriate it and implement it in their own communities in order to test its value in different policy contexts. I-GAMMA's goal is the establishment of a Participative PCD Resource Center, which can support citizen efforts to improve policy coherence for sustainable development in their communities. PCD must become more participative if it is to successfully promote the transformative development pursued by the SDGs.

Author Contributions: H.K. is responsible for oversight/coordination of research on policy coherence for development within the I-GAMMA project. In terms of this article, he is responsible for conceptualization, literature reviews, methodology, formal analysis, writing (both original draft preparation and review/editing). A.C. collected data on Mexican federal sustainable development legislation and Aguascalientes state legislation. He also conducted interviews in Mexico City with government officials, representatives of national NGOs and academic experts. He wrote I-GAMMA reports on the governance of PNAs in Mexico at the federal level and at the state level in Aguascalientes. I.P. conducted data collection and interviews with government officials, representatives of NGOs, residents of PNAs and academic experts in Veracruz State. He wrote an I-GAMMA report on the governance of PNAs in Veracruz State. H.K. is responsible for data analysis on PCD in Mexico. The entire research team conducted data analysis on governance of protected natural areas in Mexico. All authors have read and agreed to the published version of the manuscript.

Funding: This research was funded by the Consejo Nacional de Ciencia y Tecnología (CONACYT), Mexico, grant number 296842 "Uso de big data para la gestión ambiental del desarrollo sostenible (Integralidad Gamma)".

Acknowledgments: The authors wish to thank Miguel Equihua, Octavio Perez-Maqueo, Arturo Hernández Huerta, Carmen Maganda, Sandra Häbel, Julia Ros Cuellar for their guidance and feedback.

Conflicts of Interest: The authors declare no conflict of interest. 


\section{Appendix A : Methodological Tables}

Table A1. Vertical Coherence for Development.

\begin{tabular}{|c|c|c|c|}
\hline Interaction & Name & Explanation & Example \\
\hline+3 & Indivisible & $\begin{array}{c}\text { Inextricably linked to the achievement of } \\
\text { a policy goal at different levels of } \\
\text { governance }\end{array}$ & $\begin{array}{l}\text { Coordinated federal, state and/or } \\
\text { municipal programs that pursue the same } \\
\text { policy objectives and make reference to } \\
\text { each other }\end{array}$ \\
\hline+2 & Reinforcing & $\begin{array}{l}\text { Aids the achievement of a policy goal at } \\
\text { different levels of governance }\end{array}$ & $\begin{array}{c}\text { Federal, state and/or municipal programs } \\
\text { that pursue the same policy objectives } \\
\text { without coordination }\end{array}$ \\
\hline+1 & Enabling & $\begin{array}{l}\text { Creates conditions that further } \\
\text { achievement of a policy goal at different } \\
\text { levels of governance }\end{array}$ & $\begin{array}{l}\text { Federal, state and/or municipal programs } \\
\text { that pursue similar policy objectives } \\
\text { through different approaches }\end{array}$ \\
\hline 0 & Consistent & $\begin{array}{l}\text { No significant positive or negative } \\
\text { interactions. }\end{array}$ & $\begin{array}{c}\text { Federal, state and/or municipal programs } \\
\text { that do not interact }\end{array}$ \\
\hline-1 & Constraining & $\begin{array}{l}\text { Limits options for the achievement of a } \\
\text { policy goal through constraints at } \\
\text { different levels of governance }\end{array}$ & $\begin{array}{l}\text { Federal, state and/or municipal programs } \\
\text { that limit the implementation of policies } \\
\text { at other levels }\end{array}$ \\
\hline-2 & Counteracting & $\begin{array}{l}\text { Creates conditions that prevent the } \\
\text { achievement of a policy goal through } \\
\text { diverging interests at different levels of } \\
\text { governance }\end{array}$ & $\begin{array}{c}\text { Federal, state and/or municipal programs } \\
\text { that pursue diverging policy objectives } \\
\text { without open conflict. }\end{array}$ \\
\hline-3 & Canceling & $\begin{array}{l}\text { Creates conditions that prevent the } \\
\text { achievement of a policy goal through an } \\
\text { open conflict between different levels of } \\
\text { governance }\end{array}$ & $\begin{array}{c}\text { Federal, state and/or municipal programs } \\
\text { that pursue divergent policy objectives, } \\
\text { creating open conflict between levels of } \\
\text { governance. }\end{array}$ \\
\hline
\end{tabular}

Source: Table compiled by authors.

Table A2. Inter-donor Coherence for Development.

\begin{tabular}{|c|c|c|c|}
\hline Interaction & Name & Explanation & Example \\
\hline+3 & Indivisible & $\begin{array}{c}\text { Inextricably linked to the achievement of } \\
\text { a policy goal through inter-donor } \\
\text { partnership }\end{array}$ & $\begin{array}{l}\text { Integrated funding within } \\
\text { programs/projects: multi-donor programs }\end{array}$ \\
\hline+2 & Reinforcing & $\begin{array}{l}\text { Aids the achievement of a policy goal } \\
\text { through inter-donor cooperation }\end{array}$ & $\begin{array}{l}\text { Coordinated funding that pursues the } \\
\text { same policy objectives: Existence of } \\
\text { parallel programs/projects }\end{array}$ \\
\hline+1 & Enabling & $\begin{array}{l}\text { Creates conditions that further the } \\
\text { achievement of a policy goal through } \\
\text { unintentional mutual reinforcement }\end{array}$ & $\begin{array}{l}\text { Uncoordinated funding that pursues } \\
\text { similar policy objectives }\end{array}$ \\
\hline 0 & Consistent & $\begin{array}{l}\text { No significant positive or negative } \\
\text { interactions. }\end{array}$ & $\begin{array}{l}\text { Funding for programs/projects where } \\
\text { there is no relationship }\end{array}$ \\
\hline-1 & Constraining & $\begin{array}{l}\text { Limits options for the achievement of a } \\
\text { policy goal through unintentional and } \\
\text { indirect impacts }\end{array}$ & $\begin{array}{l}\text { Uncoordinated funding that } \\
\text { unintentionally and indirectly affects } \\
\text { programs from other donors negatively }\end{array}$ \\
\hline-2 & Counteracting & $\begin{array}{l}\text { Limits options for the achievement of a } \\
\text { policy goal through unintentional but } \\
\text { direct impacts }\end{array}$ & $\begin{array}{l}\text { Uncoordinated funding that } \\
\text { unintentionally but directly affects } \\
\text { programs from other donors negatively }\end{array}$ \\
\hline-3 & Canceling & $\begin{array}{l}\text { Limits options for the achievement of a } \\
\text { policy goal through intentional } \\
\text { undermining }\end{array}$ & $\begin{array}{l}\text { Funding that intentionally affects } \\
\text { programs from other donors negatively } \\
\text { due to divergent policy objectives }\end{array}$ \\
\hline
\end{tabular}


Table A3. Internal Coherence for Development.

\begin{tabular}{|c|c|c|c|}
\hline Interaction & Name & Explanation & Example \\
\hline+3 & Indivisible & $\begin{array}{c}\text { Program/project means are aligned } \\
\text { efficiently and effectively with } \\
\text { policy objectives }\end{array}$ & $\begin{array}{c}\text { Integrated administration of } \\
\text { programs/projects in line with policy } \\
\text { objectives }\end{array}$ \\
\hline+2 & Reinforcing & $\begin{array}{c}\text { Program/project means are } \\
\text { sufficiently aligned with policy } \\
\text { objectives }\end{array}$ & $\begin{array}{l}\text { Program/project administration is } \\
\text { intentionally designed appropriately for } \\
\text { policy objectives but not implemented } \\
\text { efficiently or effectively }\end{array}$ \\
\hline+1 & Enabling & $\begin{array}{c}\text { Program/project means are not } \\
\text { aligned with policy objectives but } \\
\text { appropriate }\end{array}$ & $\begin{array}{l}\text { Program/project administration is } \\
\text { unintentionally designed appropriately } \\
\text { for policy objectives but not } \\
\text { implemented efficiently or effectively }\end{array}$ \\
\hline 0 & Consistent & $\begin{array}{l}\text { No significant positive or negative } \\
\text { interactions. }\end{array}$ & $\begin{array}{l}\text { Program/project administration has no } \\
\text { impacts on policy objectives }\end{array}$ \\
\hline-1 & Constraining & $\begin{array}{l}\text { Specific program/project means are } \\
\text { not aligned with policy objectives }\end{array}$ & $\begin{array}{l}\text { Specific aspects of program/project } \\
\text { administration (i.e., calendars, data } \\
\text { collection, evaluation, etc.) are designed } \\
\text { inappropriately for policy objectives }\end{array}$ \\
\hline-2 & Counteracting & $\begin{array}{l}\text { Program/project means are not } \\
\text { aligned with policy objectives }\end{array}$ & $\begin{array}{c}\text { General program/project administration } \\
\text { is designed inappropriately for policy } \\
\text { objectives creating challenges for } \\
\text { implementation }\end{array}$ \\
\hline-3 & Canceling & $\begin{array}{l}\text { Program/project means are } \\
\text { purposely not aligned with policy } \\
\text { objectives }\end{array}$ & $\begin{array}{c}\text { General program/project administration } \\
\text { is designed inappropriately for policy } \\
\text { objectives due to political rivalries } \\
\text { between actors }\end{array}$ \\
\hline
\end{tabular}

Source: Table compiled by authors.

Table A4. Inter-organizational Coherence for Development.

\begin{tabular}{|c|c|c|c|}
\hline Interaction & Name & Explanation & Example \\
\hline+3 & Indivisible & $\begin{array}{l}\text { Inextricably linked to the achievement } \\
\text { of a policy goal through integrated } \\
\text { development partnerships }\end{array}$ & $\begin{array}{c}\text { Integrated programs/projects carried } \\
\text { out through government, NGOs, } \\
\text { private sector partnerships }\end{array}$ \\
\hline+2 & Reinforcing & $\begin{array}{c}\text { Aids the achievement of a policy goal } \\
\text { through coordinated development } \\
\text { partnerships }\end{array}$ & $\begin{array}{l}\text { Coordination of separate } \\
\text { programs/projects carried out through } \\
\text { government, NGOs, private sector } \\
\text { partnerships }\end{array}$ \\
\hline+1 & Enabling & $\begin{array}{l}\text { Creates conditions that further } \\
\text { achievement of a policy goal through } \\
\text { uncoordinated but mutually } \\
\text { reinforcing government, NGO, } \\
\text { private sector activities }\end{array}$ & $\begin{array}{l}\text { Coexistence of uncoordinated but } \\
\text { mutually reinforcing } \\
\text { programs/projects carried out by the } \\
\text { government, NGOs, private sector. }\end{array}$ \\
\hline 0 & Consistent & $\begin{array}{l}\text { No significant positive or negative } \\
\text { interactions. }\end{array}$ & $\begin{array}{l}\text { Government, NGO and private } \\
\text { programs/projects that do not interact }\end{array}$ \\
\hline-1 & Constraining & $\begin{array}{l}\text { Limits options for achievement of a } \\
\text { policy goal through constraints } \\
\text { created by unintentional and indirect } \\
\text { impacts of development partnerships }\end{array}$ & $\begin{array}{l}\text { Uncoordinated programs/projects } \\
\text { from government, NGOs and private } \\
\text { sector that unintentionally and } \\
\text { indirectly undermine policy objectives }\end{array}$ \\
\hline
\end{tabular}


Table A4. Cont.

\begin{tabular}{|c|c|c|c|}
\hline Interaction & Name & Explanation & Example \\
\hline-2 & Counteracting & $\begin{array}{l}\text { Creates conditions that prevent the } \\
\text { achievement of a policy goal through } \\
\text { diverging interests of different } \\
\text { development actors }\end{array}$ & $\begin{array}{l}\text { Uncoordinated programs/projects } \\
\text { from government, NGOs and private } \\
\text { sector that unintentionally but directly } \\
\text { undermine policy objectives }\end{array}$ \\
\hline-3 & Canceling & $\begin{array}{l}\text { Creates conditions that prevent the } \\
\text { achievement of a policy goal through } \\
\text { an open conflict between different } \\
\text { development actors }\end{array}$ & $\begin{array}{l}\text { Programs/projects from government, } \\
\text { NGOs, the private sector with } \\
\text { competing goals that openly } \\
\text { contradict each other. }\end{array}$ \\
\hline
\end{tabular}

Table A5. Financial Coherence for Development.

\begin{tabular}{|c|c|c|c|}
\hline Interaction & Name & Explanation & Example \\
\hline+3 & Indivisible & $\begin{array}{l}\text { Program/project funding from } \\
\text { different sources is sufficient and } \\
\text { appropriately executed for policy } \\
\text { objectives }\end{array}$ & $\begin{array}{l}\text { Integrated funding that mutually } \\
\text { reinforces policy objectives (i.e., } \\
\text { blended development finance) }\end{array}$ \\
\hline+2 & Reinforcing & $\begin{array}{l}\text { Program/project funding from } \\
\text { individual actors is sufficient and } \\
\text { appropriate for policy objectives }\end{array}$ & $\begin{array}{c}\text { Funding remains separate, but levels } \\
\text { are sufficient, and execution is } \\
\text { appropriate }\end{array}$ \\
\hline+1 & Enabling & $\begin{array}{l}\text { Program/project funding is } \\
\text { appropriate for policy objectives but } \\
\text { not sufficient }\end{array}$ & $\begin{array}{l}\text { Program/project funding is } \\
\text { appropriately coordinated } \\
\text { and/administered, but levels are } \\
\text { insufficient }\end{array}$ \\
\hline 0 & Consistent & $\begin{array}{l}\text { No significant positive or negative } \\
\text { interactions. }\end{array}$ & There are no funding issues present \\
\hline-1 & Constraining & $\begin{array}{l}\text { Program/project funding is } \\
\text { sufficient but poorly administered }\end{array}$ & $\begin{array}{l}\text { Payment calendars do not align with } \\
\text { program/project needs, thus } \\
\text { undermining policy objectives }\end{array}$ \\
\hline-2 & Counteracting & $\begin{array}{l}\text { Program/project funding is } \\
\text { insufficient and poorly administered }\end{array}$ & $\begin{array}{l}\text { Budget amounts are insufficient to } \\
\text { reach policy goals, and administration } \\
\text { problems exist such as problems with } \\
\text { transfers of funds between actors }\end{array}$ \\
\hline-3 & Canceling & $\begin{array}{l}\text { Program/project funding in a policy } \\
\text { arena deliberately undermines } \\
\text { policy objectives }\end{array}$ & Subsidies pursue competing goals \\
\hline
\end{tabular}

Source: Table compiled by authors.

Table A6. Normative Coherence for Development.

\begin{tabular}{|c|c|c|c|}
\hline Interaction & Name & Explanation & Example \\
\hline+3 & Indivisible & $\begin{array}{l}\text { Intentionally and directly mutually } \\
\text { reinforcing norms }\end{array}$ & $\begin{array}{c}\text { Formal and substantive normative } \\
\text { commitments to all four dimensions } \\
\text { of sustainable development }\end{array}$ \\
\hline+2 & Reinforcing & $\begin{array}{l}\text { Intentionally and indirectly } \\
\text { mutually reinforcing norms }\end{array}$ & $\begin{array}{c}\text { Formal normative commitments to all } \\
\text { four dimensions of sustainable } \\
\text { development }\end{array}$ \\
\hline+1 & Enabling & $\begin{array}{l}\text { Creates conditions that further } \\
\text { sustainable development }\end{array}$ & $\begin{array}{c}\text { General normative discourse in favor } \\
\text { of sustainable development }\end{array}$ \\
\hline 0 & Consistent & $\begin{array}{l}\text { No significant positive or negative } \\
\text { interactions. }\end{array}$ & $\begin{array}{l}\text { Absence of normative elements in } \\
\text { policy debates }\end{array}$ \\
\hline
\end{tabular}


Table A6. Cont.

\begin{tabular}{cccc}
\hline Interaction & Name & Explanation & Example \\
\hline-1 & Constraining & $\begin{array}{c}\text { General normative resistance to } \\
\text { specific dimensions of sustainable } \\
\text { development. }\end{array}$ & $\begin{array}{c}\text { General normative discourse against } \\
\text { conservation as antithesis to } \\
\text { "progress" }\end{array}$ \\
\hline-2 & Counteracting & $\begin{array}{c}\text { Unintentionally and/or indirectly } \\
\text { clashing norms }\end{array}$ & $\begin{array}{c}\text { Formal normative commitments that } \\
\text { undermine sustainable development } \\
\text { objectives. }\end{array}$ \\
\hline-3 & Canceling & Intentionally and directly clashing \\
norms & $\begin{array}{c}\text { Formal and substantive normative } \\
\text { commitments that undermine } \\
\text { sustainable development objectives. }\end{array}$ \\
\hline
\end{tabular}

Source: Table compiled by authors.

\section{References}

1. OECD. Policy Coherence for Development: Promoting Institutional Good Practice; OECD: Paris, France, 2005.

2. Picciotto, R. The Evaluation of Policy Coherence for Development. Evaluation 2005, 11, 311-330. [CrossRef]

3. Siitonen, L. Theorising Politics Behind Policy Coherence for Development (PCD). Eur. J. Dev. Res. 2016, 28, 1-12. [CrossRef]

4. Koch, D.-J. Measuring long-term trends in policy coherence for development. Dev. Policy Rev. 2018, 36, 87-110. [CrossRef]

5. Nilsson, M.; Chisholm, E.; Griggs, D.; Howden-Chapman, P.; McCollum, D.; Messerli, P.; Neumann, B.; Stevance, A.-S.; Visbeck, M.; Stafford-Smith, M. Mapping interactions between the sustainable development goals: Lessons learned and ways forward. Sustain. Sci. 2018, 13, 1489-1503. [CrossRef] [PubMed]

6. Le Blanc, D. Towards integration at last? The sustainable development goals as a network of targets. Sustain. Dev. 2015, 23, 176-187. [CrossRef]

7. Graham, S.; Graham, V. Quality political participation and the SDGs in African small island developing states. Reg. Cohes. 2019, 9, 1-30. [CrossRef]

8. King, M. Broadening the Global Development Framework Post 2015: Embracing Policy Coherence and Global Public Goods. Eur. J. Dev. Res. 2016, 28, 13-29. [CrossRef]

9. OECD. OECD Recommendation on Policy Coherence for Sustainable Development; OECD: Paris, France, 2019.

10. Hernández-Huerta, A.; Equihua Zamora, M.; Pérez-Maqueo, O. ¿Puede el desarrollo ser sostenible, integral y coherente? Reg. Cohes. 2018, 8, 1-14. [CrossRef]

11. Available online: https://www.facebook.com/IGammaNet/ (accessed on 14 February 2020).

12. Koff, H.; Equihua Zamora, M.; Maganda, C.; Pérez-Maqueo, O. Ecosystem integrity and policy coherence for development. Reg. Cohes. 2016, 6, 77-92. [CrossRef]

13. Dubé, L.; Addy, N.; Blouin, C.; Drager, N. From policy coherence to 21st century convergence: A whole-of-society paradigm of human and economic development. Ann. N. Y. Acad. Sci. 2014, 1331, 201-215. [CrossRef]

14. Personal exchange with African Development Professionals in September 2019 Seminar Organized by the Global Development Network in Luxembourg with Fellows from EIB-GDN Program in Applied Development Finance. Available online: http://www.gdn.int/sites/default/files/Applied\%20Development\%20Finance.pdf (accessed on 14 May 2020).

15. Thede, N. Policy Coherence for Development and Securitisation: Competing paradigms or stabilising North-South hierarchies? Third World Q. 2013, 84, 784-799. [CrossRef]

16. Koff, H.; Maganda, C. The EU and The Human Right to Water and Sanitation: Normative Coherence as the Key to Transformative Development. Eur. J. Dev. Res. 2016, 28, 91-110. [CrossRef]

17. Häbel, S. Normative Policy Coherence for Development and policy networks: EU networks in Vietnam. Reg. Cohes. 2020, 10, 1-21. [CrossRef]

18. Carbone, M.; Keijzer, N. The European Union and Policy Coherence for Development: Reforms, Results, Resistance. Eur. J. Dev. Res. 2016, 28,30-43. [CrossRef]

19. Larsson, M. Navigating through contradictory rationalities: Experiences of development in Mexico. Reg. Cohes. 2018, 8, 70-93. [CrossRef] 
20. OECD. Building Blocks for Policy Coherence for Development; OECD: Paris, France, 2009.

21. OECD. Better Policies for Sustainable Development 2016. In A New Framework for Policy Coherence; OECD: Paris, France, 2016.

22. European Union. Policy Coherence for Development: 2015 EU Report; European Union: Brussels, Belgium, 2015.

23. Keijzer, N. Expectation Management? Contrasting the EU's 2030 Agenda Discourse with Its Performance in Evaluating Policy Coherence for Development. Eur. Foreign Aff. Rev. 2017, 22, 177-195. Available online: https://kluwerlawonline.com/journalarticle/European\%20Foreign\%20Affairs\%20Review/22.2/18858 (accessed on 14 February 2020).

24. OECD. Mexico. Country Profiles: Institutional Mechanisms for Policy Coherence; OECD: Paris, France, 2018.

25. Lizama-Pérez, F.; Piñar-Alvarez, A.; Ortega-Argueta, A.; Mesa-Jurado, M.A.; Sandoval-Caraveo, M.C.; Carrera-Hernández, A.P. Implementation and performance of Agenda 21 for local governments in Mexico. Reg. Cohes. 2018, 8, 15-44. [CrossRef]

26. World Bank. GDP-Mexico. World Bank Open Data. Available online: https://data.worldbank.org/indicator/ NY.GDP.MKTP.CD?locations=MX (accessed on 24 January 2020).

27. CONEVAL. Medición Multidimensional de la Pobreza en México: Un Enfoque de Bienestar Económico y de Derechos Sociales; CONEVAL: Mexico City, Mexico, 2016.

28. Environmental Performance Index. Available online: https://epi.envirocenter.yale.edu/epi-topline (accessed on 20 February 2020).

29. Maass, M.; Balvanera, P.; Bourgeron, P.; Equihua, M.; Baudry, J.; Dick, J.; Forsius, M.; Halada, L.; Krauze, K.; Nakaoka, M.; et al. Changes in biodiversity and trade-offs among ecosystem services, stakeholders, and components of well-being the contribution of the International Long-Term Ecological Research network (ILTER) to Programme on Ecosystem Change and Society (PECS). Ecol. Soc. 2016, 21, 31. [CrossRef]

30. Villasis Keever, R.; Arista Castillo, L. The Perception of Urban Insecurity and Its Implications for Sustainable Development. In Sustainable Development Research and Practice in Mexico and Selected Latin American Countries; Leal Filho, W., Noyola-Cherpitel, R., Medellín-Milán, P., Ruiz Vargas, V., Eds.; Springer: Cham, Switzerland, 2018.

31. Zeigermann, U. Policy Coherence for Sustainable Development: A Promising Approach for Human Security in Fragile States. J. Peacebuilding Dev. 2020. [CrossRef]

32. Carbone, M. Mission Impossible: The European Union and Policy Coherence for Development. J. Eur Integr. 2008, 30, 323-342. [CrossRef]

33. Koff, H. Diaspora Philanthropy in the Context of Policy Coherence for Development: Implications for the post-2015 Sustainable Development Agenda. Int. Migr. 2017, 55, 5-19. [CrossRef]

34. Koff, H. and Maganda, C. Saving the baby while discarding the bathwater: The application of policy coherence for development analysis to payment for watershed services. Madera Bosques 2019, 25, e2531760. [CrossRef]

35. Challenger, A.; INECOL, Mexico; Portillo, I.; INECOL, Mexico. Personal communications, 2019.

36. Available online: https://www.iucn.org/theme/protected-areas/about (accessed on 18 February 2020).

37. Lockwood, M. Good governance for terrestrial protected areas: A framework, principles and performance outcomes. J. Environ. Manag. 2010, 91, 754-766. [CrossRef] [PubMed]

38. Bennet, N.; Dearden, J. Why local people do not support conservation: Community perceptions of marine protected area livelihood impacts governance and management in Thailand. Mar. Policy 2014, 44, 107-116. [CrossRef]

39. Challenger, A. Los Problemas que Amenazan las Areas Naturales Protegidos (ANP) de México. I-GAMMA Research Report 2020. submitted.

40. Challenger, A. Utilización y conservación de los ecosistemas terrestres de México: Pasado, presente y futuro; Comisión Nacional para el Conocimiento y Uso de la Biodiversidad, Instituto de Biología; UNAM y Agrupación Sierra Madre, SC: Tlalpan, México, 1998.

41. Cortez, C.; Paré, L. Conflicting rights, environmental agendas, and the challenges of accountability: Social mobilisation and protected natural areas in Mexico. In Rights, Resources and the Politics of Accountability; Newell, P., Wheeler, J., Eds.; Zed Books: London, UK, 2006; pp. 101-121.

42. Brenner, L. Gobernanza ambiental, actores sociales y conflictos en las Áreas Naturales Protegidas mexicanas. Revista Mexicana de Sociología 2010, 72, 283-310. [CrossRef] 
43. Paavola, J. Protected Areas Governance and Justice: Theory and the European Union's Habitats Directive. Environ. Sci. 2004, 1, 59-77. [CrossRef]

44. Ellwood, E.; Crimmins, T.; Miller-Rishing, A. Citizen science and conservation: Recommendations for a rapidly moving field. Biol. Conserv. 2017, 208, 1-4. [CrossRef]

45. Turbé, A.; Barba, J.; Pelacho, M.; Mudgal, S.; Robinson, L.D.; Serrano-Sanz, F.; Sanz, F.; Tsinaraki, C.; Rubio, J.-M.; Schade, S. Understanding the Citizen Science Landscape for European Environmental Policy: An Assessment and Recommendations. Citiz. Sci. Theory Pract. 2019, 4, 34. [CrossRef]

46. Rasmussen, L.M.; Cooper, C. Citizen Science Ethics. Citiz. Sci. Theory Pract. 2019, 4. [CrossRef]

47. Rogowski, R. Commerce and Coalitions; Princeton University Press: Princeton, NJ, USA, 1989.

48. Koff, H.; University of Luxembourg and INECOL, Mexico. Personal communications, 2017.

49. Loomis, J.; Dziedzic, M. Evaluating EIA systems' effectiveness: A state of the art. Environ. Impact Assess. Rev. 2018, 68, 29-37. [CrossRef]

50. Morgon, R. Conceptualising best practice in impact assessment. Environ. Impact Assess. Rev. 2017, 66, 78-85. [CrossRef]

51. Sadler, B.; Aschemann, R.; Dusík, J.; Fischer, T.B.; Partidário, M.R.; Verheem, R. Handbook of Strategic Environmental Assessment; Earthscan: London, UK, 2011.

52. Jordan, A.; Lenschow, A. Environmental Policy Integration: A State of the Art Review. Environ. Pol. Gov. 2010, 20, 147-158. [CrossRef]

53. Gray, S.; Jordan, R.; Crall, A.; Newman, G.; Hmelo-Silver, C.; Huang, J.; Novak, W.; Mellor, D.; Frensley, T.; Prysby, M.; et al. Combining participatory modelling and citizen science to support volunteer conservation action. Biol. Conserv. 2017, 208, 76-86. [CrossRef]

54. Keijzer, N.; Klingebiel, S.; Örnemark, C.; Scholtes, F. Seeking Balanced Ownership in Changing Development Cooperation Relationships; EBA Rapport 2018:08; Stockholm, Expert Group for Aid Studies: Stockholm, Sweden, 2018.

55. Tosun, J.; Leininger, J. Governing the Interlinkages between the Sustainable Development Goals: Approaches to Attain Policy Integration. Glob. Chall. 2017, 1, 1700036. [CrossRef]

56. Palerm, J.; Aceves, C. Environmental impact assessment in Mexico: An analysis from a 'consolidating democracy' perspective. Impact Assess. Proj. Apprais. 2004, 22, 99-108. [CrossRef]

57. Hysing, E. Representative democracy, empowered experts, and citizen participation: Visions of green governing. Environ. Pol. 2013, 22, 955-974. [CrossRef]

58. Wong, R.; van der Heijden, J. Avoidance of conflicts and trade-offs: A challenge for the policy integration of the United Nations Sustainable Development Goals. Sustain. Dev. 2019, 27, 838-845. [CrossRef]

59. Tejada, J.-C.; Alfaro de la Torre, M.-C.; Medellín Milán, P. Present Status of the Implementation of Strategic Environmental Assessment in Mexico. J. Environ. Assess. Policy Manag. 2014, 16, 1-20. [CrossRef]

60. Meadowcroft, J.; Steurer, R. Assessment practices in the policy and politics cycles: A contribution to reflexive governance for sustainable development? J. Environ. Policy Plan. 2018, 20, 734-751. [CrossRef]

61. Alès, C.; Puerta Silva, C. En las márgenes de los Estados: Participación política y formaciones ciudadanas en América Latina. Reg. Cohes. 2017, 7, 1-7. [CrossRef]

62. Koff, H. Policy coherence for development and migration: Analyzing US and EU policies through the lens of normative transformation. Reg. Cohes. 2017, 7, 5-33. [CrossRef] 